\title{
Advancing Task Involvement, Intrinsic Motivation and Metacognitive Regulation in Physical Education Classes: The Self-Check Style of Teaching Makes a Difference
}

\author{
Athanasios Papaioannou*, Argiris Theodosiou, Marina Pashali, Nikolaos Digelidis \\ Department of Physical Education and Sport Science, University of Thessaly, Trikala, Greece \\ Email: "sakispap@pe.uth.gr
}

Received March 12 $2^{\text {th }}, 2012$; revised April 14 $4^{\text {th }}, 2012$; accepted April $30^{\text {th }}, 2012$

\begin{abstract}
It was hypothesized that "self-check" style of teaching would be more preferable in terms of creating a mastery-oriented climate, and promoting adaptive achievement goals, intrinsic motivation and metacognitive activity in physical education classes. Two hundred seventy-nine $(N=269) 6$-grade students were randomly divided into two groups that were taught four consecutive physical education lessons of the same content following either "practice" or "self-check" styles of teaching respectively. Students responded on questionnaires prior and after the intervention. Results revealed significant interactions between groups and measurements. Students in the "self-check" style group scored higher in scales measuring mastery-oriented climate, mastery goal, intrinsic motivation and metacognitive processes and lower in scales measuring performance-goals and performance-oriented motivational climate. These results underscore the importance of using styles of teaching that enhance opportunities for deep cognitive processing and promote mastery-goals and mastery-oriented climates.
\end{abstract}

Keywords: Self-Check; Achievement Goals; Metacognition

\section{Introduction}

The term "teaching style" was firstly established by Mosston (1966), who organized all the teaching methods depending on whether the decisions in a teaching/learning event are made by: the teacher or the student. Later on, together with Ashworth (Mosston \& Ashworth, 1986, 1994, 2002) he proposed "the spectrum of teaching styles" on which eleven teaching methods were classified starting with the "command" style (where all the decisions are made by the teacher) and ending with the "self-teaching" style (where all the decisions are made by the student). Several studies used the spectrum in order to evaluate different styles of teaching and their impact on motor skills acquisition (e.g. Abd Al-Salam, 2004; AlMulla-Abdullah, 2003; Beckett, 1990; Boyce, 1992; Goldberger \& Gerney, 1986; Goldberger, Gerney, \& Chamberlain, 1982), while other studies explored changes on learner's motivational variables (Chatoupis \& Emmanouel, 2003; Goudas, Biddle, Fox, \& Underwood, 1995; Morgan, Kingston, \& Sproule, 2005).

The present study follows the second line of research by investigating the effects of "self-check" and "practice" teaching styles on students' cognitions and intrinsic motivation in physical education. Two accepted theoretical frameworks in educational psychology were used. Firstly, according to achievement goal theory (Ames, 1984; Ames \& Archer, 1988; Dweck \& Legget, 1988; Nicholls, 1984, 1989), in achievement settings such as physical education, two major types of goals predominate. When performance goals are adopted individuals judge success or failure in comparison to others. They feel successful if they outperform others or surpass a high normative performance aiming to demonstrate evidence of high ability or to avoid showing evi-

"Corresponding author. dence of low ability. When mastery goals are adopted individuals judge success against with their previous performance and feel successful when they manage to achieve the task and gain ability. As a result, mastery-oriented students are not afraid of facing challenging tasks. Instead, they are often intrinsically motivated in learning conditions, and this is even more profound when they can adjust task challenge to their level of abilities. In such cases mastery-oriented students apply high effort to master a task whereas learning and personal improvement is their ultimate goal.

An additional distinction of these two types of achievement goals was made by Elliot (1999) who suggested that it is also important to explore whether individuals focus on reaching a positive desirable possibility (approach goal) or on avoiding a negative undesirable possibility (avoidance goal). Combining these two dimensions with task- and ego-goals, Elliot (1999) proposed a new framework with four dimensions: performanceapproach goal (individuals try to indicate high normative ability), performance-avoidance goal (individuals try to avoid showing evidence of low ability), mastery-approach goal (individuals focus on improving personal competence on a task) and mastery goal (individuals focus on avoiding to perform poorly regarding their personal standards).

These differences in people's goals and corresponding behaveiors may derive from previous experiences (Stipek \& Hoffman, 1980), family or social influences (Ames \& Archer, 1987; Gottfried, Fleming, \& Gottfried, 1994, Papaioannou, Ampatzoglou, Kalogiannis, \& Sagovits, 2008; Parsons, Adler, \& Kaczala, 1982; Xiang, McBride, \& Bruene, 2003), or teachers' behavior (Carr \& Weigand, 2002; Marshall \& Weistein, 1986; Viciana, Cervello, \& Ramirez-Lechga, 2007; Weinstein \& Middlestadt, 1979). In particular, teachers' way of instruction, evaluation, type of feed- 
back and the tasks chosen for teaching, are important dimensions of class structure (Epstein, 1989), which determine students perceptions of their class motivational climate as being high or low mastery-oriented and high or low performance-oriented (Ames, 1992).

Overall (Dweck \& Legget, 1988; Ford, Smith, Weissbein, Gully, \& Salas, 1998; Nicholls, 1984, 1989; Pintrich, 2000; Vrugt $\&$ Oort, 2008), it is well established that performance goals and performance climates - with the exception of performance-approach goals in particular circumstances (Hidi \& Haravkiewicz, 2000)_produce maladaptive behaviours such as surface processing, shallow learning, and use of self-handicapping strategies. On the contrary, mastery-goals and mastery-oriented climates produce adaptive behaviors, emotions and cognitions, such as deep processing (Pintrich \& Garcia, 1991; Thill \& Brunel, 1995), enjoyment (Cunningham \& Xiang, 2008), persistence on effort (Guan, Xiang, McBride, \& Bruene, 2006; McCarthy, Jones, \& Clark-Carter, 2008) and self-regulated learning (Duda, Cumming, \& Balaguer, 2005).

The general framework of self-regulation and the more specific theory of metacognition (Brown, 1987; Flavell, 1979) constituted the second theoretical background of this study. Selfregulated learners are supposed to act autonomously, guiding their learning processes towards their goals, transferring previous knowledge to related situations, monitoring their progress continuously and adjusting their strategies in the face of difficulties. Self-regulation is largely a cognitive process, entails the interaction of personal and environmental variables and as a result differentiates between people of different experience (Bandura, 1986; 1997; Carver \& Scheier, 1998; Crews, 1993; Kirschenbaum, 1984; 1987; Kirschenbaum \& Wittrock, 1984; Petlichkoff, 2003; Zimmerman, 1986).

According to Efklides (2001) and others (e.g. Chen \& Singer, 1992; Ommundsen, 2006; Pintrich \& De Groot, 1990; Vrugt \& Oort, 2008) an important element of self-regulation is metacognition. Although more theoretical research is necessary to achieve an inclusive definition of metacognition (Veenman, Van HoutWolters, \& Afflerbach, 2006), literature on this field mainly identifies three strongly intercorrelated features of metacognition: knowledge of cognition, regulation of cognition and metacognitive experiences (Brown, 1987; Flavell, 1979; Jacobs \& Paris, 1987; Otero \& Campanario, 1992; Veenman, Van HoutWolters, \& Afflerbach, 2006).

Knowledge of cognition refers to a person's awareness about his/her strengths and weaknesses, awareness about the interplay between personal factors and the demands of the new situation and awareness about the usage of the strategies he/she possesses to solve a learning problem. Cross and Paris (1988) mentioned three kinds of knowledge of cognition: declarative knowledge (knowledge about the self and personal strategies), procedural knowledge (knowledge about how to use personal strategies) and conditional knowledge (knowledge about when and why to use these strategies).

However, it is essential to stress the importance of the regulating these cognition processes. Regulation of cognition consists of the activities/skills which the person uses to control his/her learning, such as: management of the available information, planning, self-monitoring, strategies for solving an on-line problem and evaluation of the learning products or the strategies that had been used (Brown, 1987).

Learning experiences are always related with cognitive processes and person's metacognitive skills developed or facilitated through appropriate teaching strategies. Metacognitive experiences refer to the feelings the person experiences in relation to a particular learning task and judgments regarding the processing of his/her learning, such as feeling of difficulty, feeling of familiarity, feeling of how well he/she is doing, etc. (Efklides, 2001).

Studies in sport and physical education confirmed that selfregulation and metacognition have strong association with mastery goals and mastery-oriented climates (Gano-Overway, 2008; Ommundsen, 2003; 2006; Papaioannou, Simou, Kosmidou, Milosis, \& Tsigilis, 2009; Solmon \& Boone, 1993; Solmon \& Lee, 1997; Theodosiou, 2004; Theodosiou \& Papaioannou, 2006; Theodosiou, Mantis, \& Papaioannou, 2008). The results of these studies supported the assumption of educational psychologists (Ames \& Archer, 1988; Boekaerts, 1997; Vrugt \& Oort, 2008) that the pursuit of mastery goals creates the appropriate substratum for the establishment of metacognition and self-regulation; however, these studies do not allow inferences about causality. For example, as self-regulated learning is ubiquitous in educational research nowadays, specific training programmes which encourage self-regulated learning have been found to be very helpful for students' learning in academic domain (Loyens, Joshua, \& Rikers, 2008). Such kind of research and especially fieldbased studies in the domain of physical education are required to draw conclusions about the appropriate instructional formats which ensure the development of students' self-regulatory strategies.

\section{Research Hypothesis}

Based on the main characteristics of the "self-check" style of teaching one can hypothesize that learners are facilitated in setting process goals (e.g. definition of process, Zimmerman \& Kitsantas, 1996, 1997). One of the main characteristics of this style of teaching is learners' self-assessment through criteria provided by the teacher (Mosston \& Ashworth, 2002). In particular, the physical education teacher prepares criteria sheets for the students, regarding the motor skill that has to be learned. Through these criteria sheets the learners become aware of the core components of the motor skill and they are able to judge the accuracy of their practice giving themselves personal feedback for every trial or for a set of trials. In addition, increased opportunities are offered to pupils to learn how to regulate their learning by monitoring their progress, by setting process goals and by focusing on the key mechanisms of the skill under practice. By this way learners become more independent and use strategies facilitating cognitive involvement which are called self-assessment strategies because by using them learners are able to asses their own skill performance (Byra, 2000, 2006). Hence, the first research hypothesis of the study was that the use of "self-check" style of teaching can activate metacognitive processes during physical education and more particularly self-monitoring and planning which are the core components of the self-regulation (Carver \& Scheier, 1998).

Furthermore, when the teacher assists the students to focus on personal process goals the teacher establishes a task-involving climate and they become more task-involved experiencing higher levels of intrinsic motivation (Digelidis, Papaioannou, Laparidis \& Christodoulidis, 2003; Jaakkola \& Digelidis, 2007). Consequently the second research hypothesis of the study was that the use of "self-check" style of teaching should increase the students' levels of intrinsic motivation and that they would perceive 
the climate of their class as more mastery-orientated.

These positive motivational and cognitive benefits were not expected if the "practice" style of teaching was used because in this style the physical educator is the only person who is responsible to introduce the skill under learning and its' key components, to supervise the students' progress and to give skillrelated feedback providing solutions for the possible incorrect performance. By this way all given information are external, limiting pupils' opportunities to act autonomously, to become task-involved, to experience high levels of intrinsic motivation and to gain knowledge about how to monitor and to regulate their learning. Indeed, by being less task-involved, students are more likely to observe and compare their peers' performance with their own. Hence, the "practice" style of teaching was more likely to facilitate performance-approach and performance-avoidance goals and climates.

\section{Method}

\section{Sample}

Two hundred and seventy nine pupils (boys $=119$, girls $=$ 141 , did not provide gender $=19$ ) of seven public elementary schools (13 coeducational classes) participated in the study. The students were in the sixth grade and the classes were taught by seven physical education teachers (years of teaching experience $=15.28 \pm 3.09$ ). The study was conducted with the permission of the Ministry of Education and the students agreed to take part voluntarily after the collection of parents' informed consent.

\section{Design and Procedure}

Prior to the study one of the authors visited the schools which were randomly selected and informed the physical education teachers about the details of the research design. All teachers had complete knowledge and adequate experience on the spectrums' styles. Each of them was teaching to two classes of the $6^{\text {th }}$ grade except one teacher who had only one class at the sixth grade. Teachers were asked to teach one of their classes with the "practice" style of teaching and the other with the "self-check" style of teaching. The physical education teacher who had one class taught with the "self-check" style of teaching. In sum, 131 students ( $\mathrm{n}=52$ boys, $\mathrm{n}=65$ girls, $\mathrm{n}=14$ did not provide gender) were taught with the "self-check" style of teaching and 148 students ( $\mathrm{n}=67$ boys, $\mathrm{n}=76$ girls, $\mathrm{n}=5$ did not provide gender $)$ were taught with the "practice" teaching style. The intervention took place during spring and lasted two weeks (2 teaching hours per week, each of them lasting 45 minutes). One of the researchers was present in every lesson to ensure the correct execution of the experimental procedure.

Four lesson plans were prepared from the authors and were designed in the same way for all classes (a. warm-up games and activities; b. main-part activities; and c. cool-down games and activities). Warm-up and cool-down games and activities were the same for both self-check and practice groups in every lesson. During the main part of activities of each lesson, one of four football skills ( $a$. dribbling with the upper side of the foot; $b$. ball passing with inner side of the foot and ball receiving; c. ball shooting with the upper side of foot; and d. throw-in) was introduced to pupils of both groups in the same order for each class. The main part of every lesson lasted 20 minutes for all classes and contained two drills/activities. After a short descrip- tion and a demonstration of the skill under learning by physical education teachers, pupils of both groups executed 25 trials of each drill (50 trials). While physical education teachers were responsible to provide feedback to the students of the "practice" group the students of the "self-check" group were provided with skill-related feedback through criterion sheets which were prepared by the authors.

The criterion sheets included a brief description of each skill's use, four key-components of it, four pictures illustrating every key-component and a self-check form for the students to mark their success (e.g. dribbling with the upper side of the foot. Description: this skill has a main part in ball possession by your team and can be used for surpassing your opponents and for the movement in an open field area. Key components: $a$. Do I use the upper side of my foot-the place where my shoelaces are? b. Are my legs slightly bended? c. Do I keep the ball in front of my feet? d. Do I keep my head up looking at my partners?). Pupils executed ten sets of five trials (50 trials). After each set, for every key-component they indicated in the criterion sheet whether they performed the skill correctly $(\nabla)$ or they needed further improvement $(囚)$. At the end of the criterion card there was a self-assessment form where students could score their success for every set (min score: 0, max score: 4).

All participants responded to questionnaires at the end of one lesson before the intervention which was a typical lesson of their class and at the end of the final lesson of the intervention. They were informed that there were no right or wrong answers, were encouraged to answer as honestly as possible, and were assured that their responses would remain confidential. Students worked on their own but those who wanted to ask questions could communicate privately with the researcher who was present and administered the questionnaires.

\section{Measures}

All students completed the instruments after a 35 minutes class. In order to reduce completion time, shorter versions of the existing questionnaires were administered. Based on data from previous studies with these questionnaires, the best items were selected trying to ensure that these shorter versions would satisfy demands for reliability and factorial validity. As is showed below, we conducted confirmatory factor analyses to establish the factorial validity of the present measures. Moreover, we investigated correlations between the present scales to establish divergent and convergent validity. All correlation results were in line with theoretical assumptions but they are not reported here due to space limitations (however they can be provided by the authors upon request).

\section{Achievement Goals}

The Achievement Goals Scale at the Situational Level of Generality (Papaioannou, Milosis, Kosmidou, \& Tsigilis, 2007) was used to assess students' goal orientations at a particular point of time. This instrument was created to capture changes of students' achievement goals in physical education classes at a particular point of time and has been used successfully in previous studies (Papaioannou et al., 2007). We removed 9 items from this instrument, the 6 items comprising the social approval factor and one item from the mastery, performanceapproach and performance-avoidance factors respectively. Following the stem: "In today's physical education class..." Students indicated their preferences to the 15 items of this instru- 
ment in a 5 -point Likert type scale $(5=$ strongly agree, $\ldots 1=$ strongly disagree). Examples of the items are: “... my goal was to improve my skills" (mastery goal, 5 items); “... I was striving in order to be the best" (performance-approach goal, 5 items); “... I was avoiding drills and games for which I may be gibed at for my abilities" (performance-avoidance goal, 5 items). Confirmatory factor analysis revealed satisfactory goodness-of-fit indices for the three-factor model (chi square $=120.6$; $d f=87$; $T L I=.955 ; C F I=.967 ;$ RMSEA $=.037)$.

\section{Motivational Climate}

To estimate how students perceive the climate of their physical education classes three scales (mastery climate, performanceapproach climate and performance-avoidance climate) of the Perceptions of a Physical Education Teacher's Emphasis on Achievement Goals Questionnaire at the Situational level of Generality (Papaioannou et al., 2007) were used. For the aforementioned reasons and following the same procedure we also reduced the items of this questionnaire to 15 by removing the 7 items of the social approval climate and 1 item from each of the remaining factors. Following the stem: "In today's physical education class, our teacher...”, students responded in 5-point Likert type scale $(5=$ strongly agree, $\ldots 1=$ strongly disagree). Example items of this instrument are: “.... was very satisfied when someone was showing improvement after hard effort" (mastery climate, 5 items); “... was pleased with students showing that they were more capable than others" (performance approach climate, 5 items); “... made me worry if they say that I am not capable" (performance avoidance climate, 5 items). The results of the confirmatory analysis confirmed the three-factor structure of the instrument (chi square $=121.89 ; d f=89 ; T L I=.941$; $C F I=.957 ;$ RMSEA $=.038)$.

\section{Intrinsic Motivation}

The two scales (interest/enjoyment and effort/importance) of the Intrinsic Motivation Inventory (IMI) (McAuley, Duncan \& Tammen, 1989) were used to measure students' intrinsic motivation. This questionnaire is one of the most frequently used instrument in the context of sports and physical education and its psychometric properties have been established in previous studies (e.g., Tsigilis \& Theodosiou, 2003). Students answered to the items following the stem: "In today's Physical Education class..." Responses were given on 5-point Likert type scale (5 $=$ strongly agree, $\ldots 1=$ strongly disagree). Example items are: "... the activities were fun to do" (interest/enjoyment, 4 items); “... I was trying very hard" (effort/importance, 4 items). The present confirmatory analysis revealed satisfactory goodnessof-fit indices for the two-factor model (chi square $=35.5$; $d f=$ $19 ; T L I=.961 ; C F I=.979 ; R M S E A=.056)$.

\section{Metacognitive Self-Regulation}

Two scales measuring planning and self- monitoring from the Metacognitive Processes in Physical Education Questionnaire (MPIPEQ) were administered. This instrument is an enriched and adapted version for physical education of the Metacognitive Awareness Inventory (MAI) (Schraw \& Dennison, 1994), which is based on Brown's (1987) framework. Its' construct validity and reliability has been tested in previous studies (Theodosiou \& Papaioannou, 2006; Theodosiou, Papaioannou, \& Mantis, 2005; Theodosiou, Mantis, \& Papaioannou, 2008).
We were particularly interested in measuring "self-monitoring" and "planning" because these cognitive functions were expected to be activated through the use of the "self-check" style. All items were adjusted at the situational level of generality. Following the stem "In today's Physical Education class..." responses were given on 5-point Likert scales $(5=$ always, $4=$ often, 3 = sometimes, 2 = rarely, $1=$ never). Example items of the two scales are: “... it was clear to me what I wanted to learn” (planning, 4 items); “... as I was learning new exercises I was checking if I was actually doing well" (self-monitoring, 4 items). Confirmatory analysis revealed excellent goodness-offit indices for the present two-factor model (chi square $=22.6$; $d f=19 ; T L I=.990 ; C F I=.995 ; R M S E A=.026)$.

From the remaining 7 scales of the MPIPEQ we selected one item from every scale in order to capture overall metacognitive activity in physical education. These items were as follows: declarative knowledge: “... I realized which exercises I could perform right", conditional knowledge: “... when I wanted to grow better in a game I put into practice a learning strategy", procedural knowledge: "... I had a clear view of how to put in practice a learning method I have been taught", imagery: “... before I perform an exercise I imagined myself to perform it", information management: “... I thought if the games I played were similar to others", problem solving strategies: “... when I got confused I stopped to see the whole thing from the beginning”, evaluation: “... since I have learned an exercise I compared the way I had learned it with other ways". The goodness-of-fit indices for this one-factor model were satisfactory (chi square $=31.4 ; d f=14 ; T L I=.920 ; C F I=.947 ; R M S E A$ $=.067$ ).

\section{Results}

\section{Internal Consistencies and Scale Construction}

The alpha reliabilities (Cronbach, 1951) of the scales of the questionnaires for both measurements are shown in Table 1. Most of the results indicate acceptable scale reliabilities. Scale scores were computed for measurements before and after the intervention.

Descriptive statistics for these scales using each individual student as the unit of analysis are shown in Table 2. Based on Silverman's and Skonie's (1997) recommendation that experimental effects in school settings should be also studied at a class level, scale scores were also computed using class as the unit of analysis. In order to have enough sample size of classes in subsequent analyses, given the sufficient number of boys and girls

Table 1.

Internal consistency of the scales.

\begin{tabular}{lcc}
\hline & Initial measure & Final measure \\
\hline Mastery goal & .73 & .71 \\
Performance-approach goal & .78 & .78 \\
Performance-avoidance goal & .78 & .81 \\
Mastery climate & .74 & .71 \\
Performance-approach climate & .72 & .55 \\
Performance-avoidance climate & .72 & .67 \\
Enjoyment & .69 & .81 \\
Effort & .73 & .79 \\
Self-monitoring & .75 & .75 \\
Planning & .66 & .79 \\
Overall metacognitive activity & .66 & .79 \\
\hline
\end{tabular}


Table 2.

Means and standard deviations for goal orientations, motivational climate, intrinsic motivation and metacognitive self-regulation.

\begin{tabular}{|c|c|c|c|c|c|c|c|c|c|c|c|c|c|c|c|c|}
\hline \multirow{4}{*}{$\begin{array}{l}\text { Measure: } \\
\text { Teaching style: }\end{array}$} & \multicolumn{8}{|c|}{ Unit of analysis: student } & \multicolumn{8}{|c|}{ Unit of analysis: class } \\
\hline & \multicolumn{4}{|c|}{ Initial } & \multicolumn{4}{|c|}{ Final } & \multicolumn{4}{|c|}{ Initial } & \multicolumn{4}{|c|}{ Final } \\
\hline & \multicolumn{2}{|c|}{ Self-check } & \multicolumn{2}{|c|}{ Practice } & \multicolumn{2}{|c|}{ Self-check } & \multicolumn{2}{|c|}{ Practice } & \multicolumn{2}{|c|}{ Self-check } & \multicolumn{2}{|c|}{ Practice } & \multicolumn{2}{|c|}{ Self-check } & \multicolumn{2}{|c|}{ Practice } \\
\hline & $M$ & $S D$ & $M$ & $S D$ & $M$ & $S D$ & $M$ & $S D$ & $M$ & $S D$ & $M$ & $S D$ & $M$ & $S D$ & $M$ & $S D$ \\
\hline Mastery goal & $4.34^{\mathrm{a}}$ & .66 & $4.16^{\mathrm{b}}$ & .66 & $4.32^{\mathrm{a}}$ & .56 & $3.85^{\mathrm{c}}$ & .75 & $4.23^{\mathrm{d}}$ & .33 & $4.23^{\mathrm{d}}$ & .33 & $4.32^{\mathrm{d}}$ & .18 & $3.78^{\mathrm{f}}$ & .33 \\
\hline Performance-approach goal & $2.97^{\mathrm{a}}$ & .99 & $2.82^{\mathrm{a}}$ & 1.02 & $2.18^{\mathrm{b}}$ & .65 & $2.66^{\mathrm{c}}$ & 1.03 & $2.99^{\mathrm{d}}$ & .53 & $2.82^{\mathrm{d}}$ & .40 & $2.21^{\mathrm{e}}$ & .28 & $2.70^{\mathrm{d}}$ & .49 \\
\hline Performance-avoidance goal & $2.69^{\mathrm{a}}$ & 1.01 & $2.81^{\mathrm{a}}$ & .97 & $2.35^{\mathrm{b}}$ & .75 & $2.75^{\mathrm{a}}$ & .92 & $2.64^{\mathrm{d}}$ & .34 & $2.81^{\mathrm{d}}$ & .27 & $2.37^{\mathrm{e}}$ & .30 & $2.74^{\mathrm{d}}$ & .39 \\
\hline Mastery climate & $3.95^{\mathrm{a}}$ & .74 & $3.88^{\mathrm{a}}$ & .72 & $4.27^{\mathrm{b}}$ & .60 & $3.65^{\mathrm{c}}$ & .76 & $3.93^{\mathrm{d}}$ & .33 & $3.80^{\mathrm{d}}$ & .41 & $4.25^{\mathrm{e}}$ & .21 & $3.60^{\mathrm{f}}$ & .30 \\
\hline Performance-approach climate & $2.74^{\mathrm{a}}$ & .72 & $2.65^{\mathrm{a}}$ & .77 & $2.33^{\mathrm{b}}$ & .64 & $2.74^{\mathrm{a}}$ & .84 & $2.63^{\mathrm{de}}$ & .36 & $2.67^{\mathrm{df}}$ & .35 & $2.35^{\mathrm{e}}$ & .18 & $2.76^{\mathrm{f}}$ & .37 \\
\hline Performance-avoidance climate & $2.71^{\mathrm{a}}$ & .85 & $2.58^{\mathrm{a}}$ & .77 & $2.26^{\mathrm{b}}$ & .69 & $2.75^{\mathrm{a}}$ & .86 & $2.69^{\mathrm{d}}$ & .35 & $2.55^{\mathrm{d}}$ & .31 & $2.27^{\mathrm{e}}$ & .24 & $2.74^{\mathrm{d}}$ & .41 \\
\hline Enjoyment & $4.29^{\mathrm{a}}$ & .67 & $4.32^{\mathrm{a}}$ & .70 & $4.51^{\mathrm{b}}$ & .52 & $4.07^{\mathrm{c}}$ & .89 & $4.27^{\mathrm{d}}$ & .25 & $4.32^{\mathrm{d}}$ & .39 & $4.50^{\mathrm{d}}$ & .20 & $3.98^{\mathrm{e}}$ & .44 \\
\hline Effort & $4.03^{\mathrm{a}}$ & .97 & $4.05^{\mathrm{a}}$ & .80 & $4.37^{\mathrm{b}}$ & .60 & $3.74^{\mathrm{c}}$ & .99 & $4.06^{\mathrm{d}}$ & .29 & $4.03^{\mathrm{d}}$ & .29 & $4.40^{\mathrm{e}}$ & .20 & $4.03^{\mathrm{f}}$ & .29 \\
\hline Self-monitoring & $3.89^{\mathrm{a}}$ & .85 & $3.75^{\mathrm{a}}$ & .93 & $4.25^{\mathrm{b}}$ & .67 & $3.50^{\mathrm{c}}$ & .86 & $3.90^{\mathrm{d}}$ & .31 & $3.73^{\mathrm{d}}$ & .42 & $4.27^{\mathrm{e}}$ & .32 & $3.46^{\mathrm{f}}$ & .42 \\
\hline Planning & $3.87^{\mathrm{a}}$ & .85 & $3.69^{\mathrm{a}}$ & .88 & $4.20^{\mathrm{b}}$ & .63 & $3.53^{\mathrm{a}}$ & 1.02 & $3.88^{\mathrm{d}}$ & .32 & $3.69^{\mathrm{d}}$ & .42 & $4.21^{\mathrm{e}}$ & .27 & $3.50^{\mathrm{f}}$ & .35 \\
\hline Overall metacognitive activity & $3.49^{\mathrm{a}}$ & .70 & $3.42^{\mathrm{a}}$ & .63 & $4.20^{\mathrm{b}}$ & .55 & $3.36^{\mathrm{a}}$ & .68 & $3.51^{\mathrm{d}}$ & .22 & $3.43^{\mathrm{d}}$ & .24 & $4.22^{\mathrm{e}}$ & .23 & $3.36^{\mathrm{d}}$ & .20 \\
\hline
\end{tabular}

Note: Group means sharing the same subscript are not significantly different at the .05 level.

in each class (for each gender in every class: $15>n>6$ ), scale scores for each class were computed separately for each gender. Descriptive statistics for scale scores using class as the unit of analysis are shown in Table 2.

\section{Differences between "Self-Check" and "Practice" Style of Teaching}

To investigate possible differences between "self-check" and "practice" styles in goal orientations, motivational climates, intrinsic motivation, self-monitoring, planning and overall metacognitive activity, four doubly repeated measures MANOVAs were computed using student as the unit of analysis. In each of these MANOVAs, independent variable was the teaching style and depended variables were the following variables before and after the intervention: 1) The three goal orientations; 2) The three climate scales; 3) The two intrinsic motivation variables; and 4) The three metacognitive variables. Results from all doubly repeated measures MANOVAs revealed significant interaction effects of the repeated measures factor with the teaching styles factor $(p<.001)$.

To investigate these effects for each dependent variable we conducted repeated measures ANOVAs (measurement $\times$ teaching style). The results revealed significant interactions between measurement and teaching style in all depended variables (Table 3; Figures 1-11). In order to better understand these interactions separate simple effect analyses were performed (Table 2). From the initial to the final measurement, in comparison to the scores of students who were taught with the "self-check" style of teaching, the scores of students who were taught with the "practice" style were decreased for scales capturing mastery goal, mastery climate, intrinsic motivation (enjoyment and effort), overall metacognitive activity, self-monitoring and planning (Table 2, Figures 1, 3, 7-9 and 11) but they were increased for scales measuring performance goals and performance-oriented climates.

The same statistical analyses were contacted using class level as the unit of analyses. Almost similar results emerged, confirming most of our research hypotheses. Significant interacttions $(p<.001)$ emerged between the repeated measures factor and the teaching styles factor in all doubly repeated measures MANOVAs.
As it can be seen in Table 3, results from repeated measures ANOVAs (measurement $\times$ teaching style) for each dependent variable revealed significant interactions between measurement and teaching style in almost all the depended variables. Compared to classes that were taught with "self-check" style of teaching, classes that were taught with "practice" style of teaching had lower scores in the final measurement in scales measuring mastery goal, mastery-oriented climate, intrinsic motivation and metacognitive activity and higher scores in scales measuring performance goals and performance-oriented climates.

\section{Discussion}

It has been suggested that the "self-check" style of teaching assists students to set process goals (Zimmerman \& Kitsantas, 1996; Papaioannou \& Kouli, 1999). The present study tried to elaborate deeper into this matter by exploring the cognitive processes that are activated when students are taught with the "self-check" style of teaching.

The aim of this study was to verify the notion that teaching physical education skills with the "self-check teaching style" has important benefits for students' motivation and self-regulation. Specifically, it was hypothesized that the adoption of this style of teaching has positive effects on motivational climate and students' goal orientations, intrinsic motivation and metacognitive activity in physical education classes. All hypotheses were confirmed.

The results showed that the "self-check" style helps students to activate two core processes of the self-regulation system, namely, self-monitoring and planning. Through the use of the criteria sheet, pupils are asked to monitor themselves, to analyse their performance and to decide about the correctness of their actions. Then, by applying this information they are asked to set new or to re-establish process goals for the improvement of their motor performance in the next trials. Through this procedure students complete the three phases of self-regulated learning (forethought, performance, self-reflection; Zimmerman 1986; 2000) and adjust their actions by themselves using personal feedback loops which involve the activation of conscious cognitive processes. Such feedback loops constitute the basis of self-regulation (Carver \& Scheier, 1998) and the activation of them requires metacognitive knowledge and metacognitive regu- 
Table 3.

Results of the repeated measures ANOVAs (measurement $\times$ teaching style).

\begin{tabular}{lcccccc}
\hline & \multicolumn{3}{c}{ Unit of analysis: student } & \multicolumn{3}{c}{ Unit of analysis: class } \\
\cline { 2 - 7 } & $F$ & Sig. & $\eta^{2}$ & $F$ & Sig. & $\eta^{2}$ \\
\hline Mastery goal & 10.76 & .001 & .035 & 14.37 & .001 & .374 \\
Performance-approach goal & 23.53 & .000 & .079 & 14.04 & .001 & .369 \\
Performance-avoidance goal & 4.98 & .026 & .018 & 1.39 & .249 & .055 \\
Mastery climate & 28.86 & .000 & .095 & 16.32 & .000 & .405 \\
Performance-approach climate & 23.15 & .000 & .077 & 3.66 & .068 & .132 \\
Performance-avoidance climate & 30.01 & .000 & .098 & 12.71 & .002 & .346 \\
Enjoyment & 20.52 & .000 & .069 & 10.96 & .003 & .314 \\
Effort & 29.53 & .000 & .097 & 46.28 & .000 & .658 \\
Self-monitoring & 27.64 & .000 & .091 & 25.72 & .000 & .517 \\
Planning & 15.31 & .000 & .053 & 22.42 & .000 & .483 \\
Overall metacognitive activity & 69.79 & .000 & .202 & 96.48 & .000 & .801 \\
\hline
\end{tabular}

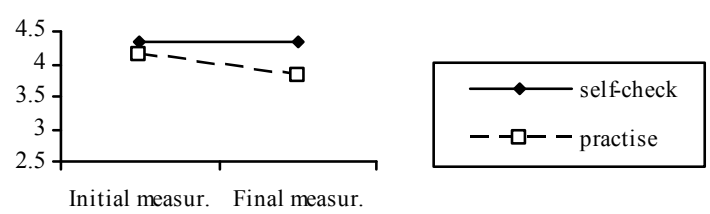

Figure 1.

Changes in mastery goal orientation.

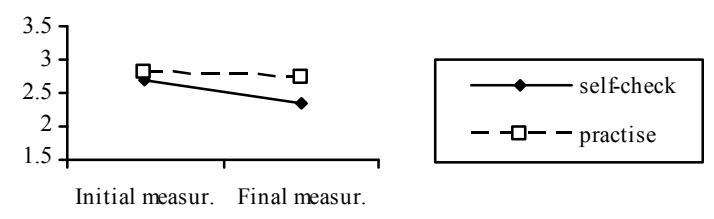

Figure 3.

Changes in performance avoidance goal orientation.
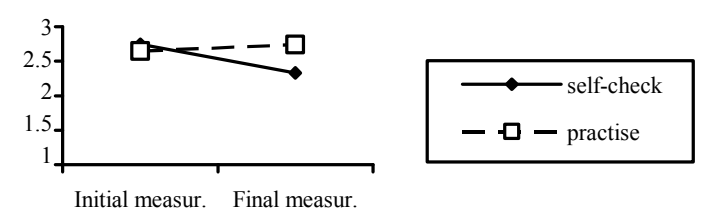

Figure 5.

Changes in performance approach motivational climate.

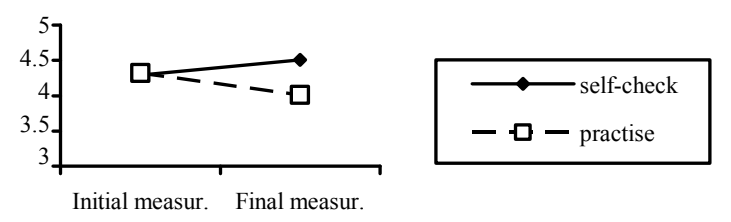

Figure 7.

Changes in enjoyment in physical education.

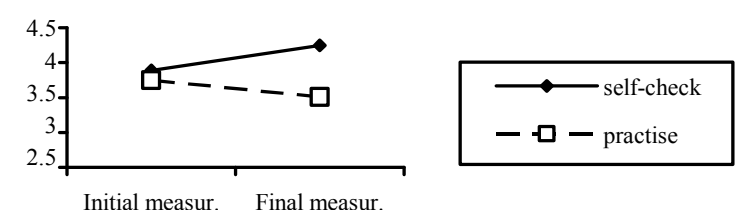

Figure 9.

Changes in self-monitoring.

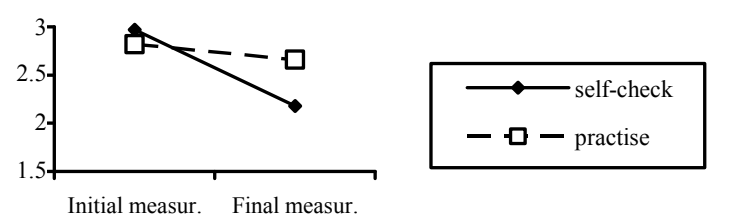

Figure 2.

Changes in performance approach goal orientation.

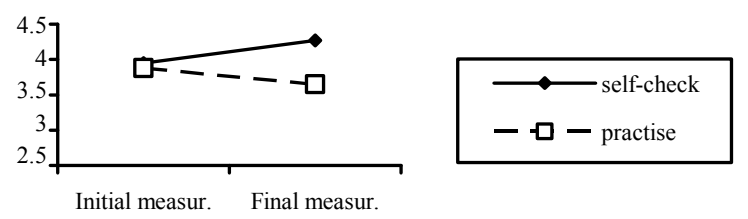

Figure 4.

Changes in mastery motivational climate.

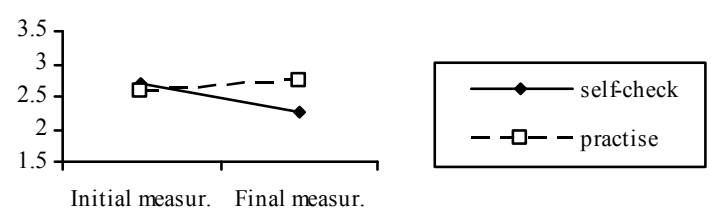

Figure 6.

Changes in performance avoidance motivational climate.

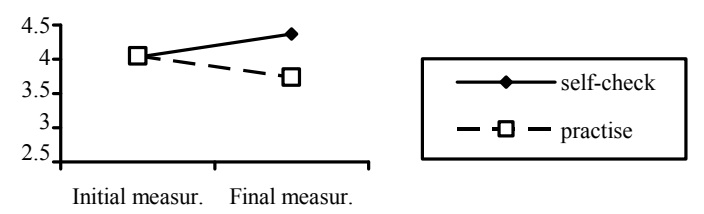

Figure 8.

Changes in effort in physical education.

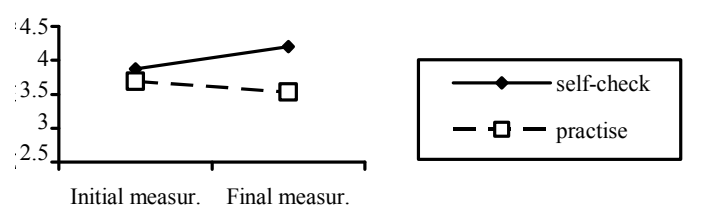

Figure 10.

Changes in planning. 


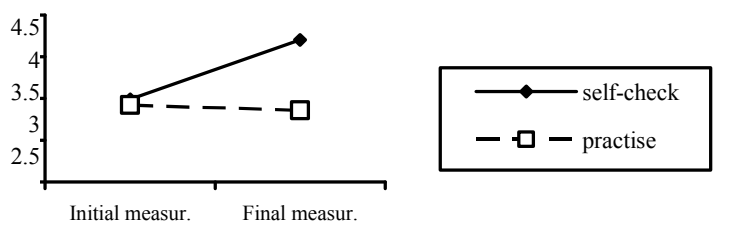

Figure 11.

Changes in general metacognitive activity.

lation. Indeed, the present findings provided strong support to this notion by revealing large effect sizes. Students who were taught the soccer skills in the "self-check" conditions were much more likely to use several components of metacognitive knowledge and regulation (i.e., overall metacognitive activity) than students who were taught with the practice style.

Apart from the cognitive benefits, the use of the "self-check" style has motivational benefits too. This study confirmed that the "self-check" style contributes to the development of a positive motivational climate which is characterized as high mastery and low performance oriented. Specifically, by setting process goals students individualize the learning process, which is an important dimension of a mastery-oriented climate (Ames, 1992). Indeed, the present findings confirmed that the "self-check" style of teaching had more positive effects on perceptions of mastery-oriented climate than the practice style. This individualized learning process helped students to sustain their attention on their learning task and to be less distracted by others' behaviours and performance in comparison to students who were taught with the "practice" style of teaching. In sum, this led to decreased perceptions of social comparison and consequently reduced perceptions of teachers' emphasis on performance approach or performance avoidance goals in the "self-check" style classes.

The positive effects of the "self-check" style on motivational climate led to positive consequences in students' adoption of mastery and performance goals. Students in "self-check" classes adopted higher mastery goals and lower performance goals than students in "practice style" classes. By being more self-regulated, students in "self-check" classes were also more autonomous learners than students in "practice style" classes. By attending less the performance of others, students' progress in "self-check" conditions was more self-determined in comparison to students in "practice style" conditions. These higher levels of autonomy and self-determination led to higher intrinsic motivation (Deci \& Ryan, 1985) for students in the "self-check" conditions in comparison to students in the "practise style" conditions.

In total, in comparison to preferable teacher-centred styles such as the "practice" style (Curtner-Smith, Todorovich, McCaughtry, \& Lacon, 2001), the present results were clearly in favour of the "self-check" style. It appears that this style of teaching establishes an educational environment which includes affordances for self-regulation. These findings refer to beginners, but further research should examine whether these implications can be generalized across students with advanced knowledge and skills because in the opinion of several researchers there are many types of self-regulated action that are more or less suitable for different tasks, in different domains, and for different students. On the subject of metacognitive regulation the present study clearly focused on self-monitoring and planning. Thus, longer interventions involving a number of combinations between "self-check" and other styles of teaching are needed, because they better reflect the multidimensionality of the teaching process than the limited number of the present classes.

\section{Implications for Physical Education Teachers}

The present findings imply that in grades $5-8$ which is a period when students are introduced to new sports skills, the use of the "self-check" style could have a prominent role in the teaching process. However, this conclusion has not to be considered as an effort to verify the supremacy of one style over another. Mosston and Ashworth (1986) emphasize that no single style of teaching is superior to another and suggest the physical education teacher to determine first what has to be accomplished and then to decide which style is more appropriate in a given situation. For example, early research findings (Beckett, 1990) confirmed that the "practise" is equivalent to the "inclusion" teaching style in cases of performing a motor skill. But between these two styles the "inclusion" style of teaching is preferable when the students are girls and when the enhancement of perceived athletic competence is the goal of the lesson, (Chatoupis \& Emmanouel, 2003). Thus, the main message of this study is that teachers concerning in promoting self-regulatory skills and in establishing a mastery-oriented climate in physical education classes can choose "self-check" style to achieve their goals. Having in mind the above, the adequate training of the physical education teachers about the implementation and the precise usefulness of each style becomes a main priority. Physical education authorities through seminars and workshops have to ensure that physical education teachers have adequate knowledge of the variety of teaching styles in order to choose which one better achieve their goals.

\section{REFERENCES}

Abd Al-Salam, A. (2004). The effects of three styles of teaching on the performance level and practice trials of long serves and short serves in badminton. Dirasat: Educational Sciences, 31, 88-104.

AlMulla-Abdullah, F. (2003). The effectiveness of the reciprocal teaching style on the level of shooting skills acquisition in team handball. Journal of Educational Psychological Science, 3, 10-37.

Ames, C. (1984). Competitive, cooperative and individualistic goal structures: A motivational analysis. In R. Ames, \& C. Ames (Eds.), Research on motivation in education. Vol. 1: Student motivation (pp. 177-207). New York: Academic Press.

Ames, C. (1992). Classrooms: Goals, structures, and student motivation. Journal of Educational Psychology, 84, 261-271. doi: $10.1037 / 0022-0663.84 .3 .261$

Ames, C., \& Archer, J. (1987). Mothers' belief about the role of ability and effort in school learning. Journal of Educational Psychology, 18, 409-414. doi:10.1037//0022-0663.79.4.409

Ames, C., \& Archer, J. (1988). Achievement goals in the classroom: Students' learning strategies and motivation processes. Journal of Educational Psychology, 80, 260-267. doi: $10.1037 / 0022-0663.80 .3 .260$

Bandura, A. (1986). Social foundation of thought and action: A social cognitive theory. Englewood Cliffs, NJ: Prentice-Hall.

Bandura, A. (1997). Self-Efficacy: The exercise of control. New York: Freeman.

Beckett, K. (1990). The effects of two teaching styles on college students' achievement of selected physical education outcomes. Journal of Teaching in Physical Education, 10, 153-169.

Boekaerts, M. (1997). Self-regulated learning: A new concept embraced by researchers, policy makers, educators, teachers and students. Learning and Instruction, 7, 161-186.

doi:10.1016/S0959-4752(96)00015-1

Boyce, B. A. (1992). The effects of three styles of teaching on univer- 
sity student's motor performance. Journal of Teaching in Physical Education, 11, 389-401.

Brown, A. (1987). Metacognition, executive control, self-regulation and other more mysterious mechanisms. In F. Weinert, \& R. Kluwer (Eds.), Metacognition, motivation and understanding (pp. 65-116). Hillsdale: Erlbaum.

Byra, M. (2000). A review of spectrum research: The contribution of two eras. Quest, 52, 229-245. doi:10.1080/00336297.2000.10491712

Byra, M. (2006). Teaching styles and inclusive pedagogies. In D. Kirk, D. MacDonald, \& M. O'Sullivan (Eds.), The handbook of physical education (pp. 449-466). London: Sage Publications.

Carr, S., \& Weigand, D. A. (2002). The influence of significant others on the goal orientations of youngsters in physical education. Journal of Sport Behavior, 25, 19-40.

Carver, C. S., \& Scheier, M. F. (1998). Self-regulation of behavior. New York: Cambridge university press. doi:10.1017/CBO9781139174794

Chen, D., \& Singer, R. N. (1992). Self-regulation and cognitive strategies in sport participation. International Journal of Sport Psychology, 23, 277-300.

Crews, D. J. (1993). Self-regulation strategies in sport and exercise. In R. N. Singer, M. Murphey, \& L. K. Tennant (Eds.), Handbook of research on sport psychology (pp. 557-568). New York: Macmillan Publishing Company.

Cronbach, L. (1951). Coefficient alpha and the internal structure of test. Psychometrika, 16, 297-334. doi:10.1007/BF0230555

Cross, D. R., \& Paris, S. G. (1988). Developmental an instructional analysis of children's metacognition and reading comprehension. Journal of Educational Psychology, 80, 131-142. doi:10.1037/0022-0663.80.2.131

Cunningham, G. B., \& Xiang, P. (2008). Testing the mediating role of motivational climate in the relationship between achievement goals and satisfaction: Are the relationships invariant across sex? Journal of Teaching in Physical Education, 27, 192-204.

Curtner-Smith, M. D., Todorovich, J. R., McCaughtry, N. A., \& Lacon, S. A. (2001). Urban teachers' use of productive and reproductive teaching styles within the confines of the National Curriculum for physical education. European Physical Education Review, 7, 177190. doi:10.1177/1356336X010072005

Deci, E. L., \& Ryan, R. M. (1985). Intrinsic motivation and self-determination in human behavior. NY: Plenum.

Digelidis, N., Papaioannou, A., Laparidis, K., \& Christodoulidis, T. (2003). A one-year intervention in 7th grade physical education classes aiming to change motivational climate and attitudes towards exercise. Psychology of Sport and Exercise, 4, 195-210. doi:10.1016/S1469-0292(02)00002-X

Duda, J. L., Cumming, J., \& Balaguer, I. (2005). Enhancing athletes' self regulation, task involvement, and self determination via psychological skills training. In D. Hackfort, J. Duda, \& R. Lidor (Eds.), Handbook of applied sport psychology research: International perspectives (pp. 143-165). Morgantown, WV: Fitness Information Technology.

Dweck, C. S., \& Leggett, E. L. (1988). A social-cognitive approach to motivation and personality. Psychological Review, 95, 256-273. doi:10.1037/0033-295X.95.2.256

Efklides, A. (2001). Metacognitive experiences in problem solving: Metacognition, motivation, and self-regulation. In A. Efklides, J. Kuhl, \& R. M. Sorrentino (Eds.), Trends and prospects in motivation research (pp. 297-323). Dordrecht: Kluwer.

Elliot, A. J. (1999). Approach and avoidance motivation and achievement goals. Educational Psychologist, 34, 169-189. doi:10.1207/s15326985ep3403 3

Epstein, J. L. (1989). Family structures and student motivation: A developmental perspective. In C. Ames, \& R. Ames (Eds.), Research on motivation in education: Vol. 3. Goals and cognitions. Orlando: Academic Press.

Flavell, J. H. (1979). Metacognition and cognitive monitoring: A new area of cognitive-developmental inquiry. American Psychologist, 34, 906-911. doi:10.1037//0003-066X.34.10.906

Chatoupis, C., \& Emmanuel, C. (2003). "The effects of two disparate instructional approaches on students" self-perceptions in elementary physical education. European Journal of Sport Science, 3, 1-16. doi:10.1080/17461390300073101

Ford, J. K., Smith, E. M., Weissbein, D. A., Gully, S. M., \& Salas, E. (1998). Relationships of goal orientation, metacognitive activity and practice strategies with learning outcomes and transfer. Journal of Applied Psychology, 83, 218-233. doi:10.1037//0021-9010.83.2.218

Gano-Overway, L. A. (2008). The effect of goal involvement on selfregulatory processes. International Journal of Sports and Exercise Psychology, 6, 132-156. doi:10.1080/1612197X.2008.9671858

Goldberger, M., \& Gerney, P. (1986). The effects of direct teaching styles on motor skill acquisition of fifth grade children. Research Quarterly for Exercise and Sport, 57, 215-219.

Goldberger, M., Gerney, P., \& Chamberlain J. (1982). The effects of three styles of teaching on the psychomotor performance of fifth grade children. Research Quarterly for Exercise and Sport, 53, 116124.

Gottfried, A. E., Fleming, J. S., \& Gottfried, A. W. (1994). Role of parental motivational practices in children's academic intrinsic motivation and achievement. Journal of Educational Psychology, 86, 104-113. doi:10.1037//0022-0663.86.1.104

Goudas, M., Biddle, S., Fox, K., \& Underwood, M. (1995). It ain’t what you do, it's the way that you do it! Teaching style affects children's motivation in track and field. The Sport Psychologist, 18, $462-471$.

Guan, J., Xiang, P., McBride, R. E., \& Bruene, A. (2006). Achievement goals, social goals, and students' reported persistence and effort in high school physical education. Journal of Teaching in Physical Education, 25, 58-74.

Hidi, S, \& Harackiewicz, J. M. (2000). Motivating the academically unmotivated: A critical issue for the 21st century. Review of Educational Research, 70, 151-179. doi:10.2307/1170660

Jaakkola, T. \& Digelidis, N. (2007). Establishing a positive motivational climate in physical education. In J. Liukkonen, Y. Vanden Auweele, B. Vereijken, D. Alfermann, \& Y. Theodorakis (Eds.), Psychology for physical educators: Student in focus ( $2^{\text {nd }}$ ed.; pp. 3-20). Champaign: Human Kinetics.

Jacobs, J., \& Paris, S. (1987). Children's metacognition about reading. Issues in definition, measurement, and instruction. Educational Psychologist, 22, 255-278. doi:10.1207/s15326985ep2203\&4 4

Kirschenbaum, D. S. (1984). Self-regulation and sport psychology: Nurturing an emerging symbiosis. Journal of Sport Psychology, 6, 159-183.

Kirschenbaum, D. S. (1987). Self-regulation and sport performance. Medicine and Science in Sports and Exercise, 19, S106-S113. doi:10.1249/00005768-198710001-00003

Kirschenbaum, D. S., \& Wittrock, D. A. (1984). Cognitive-behavioral interventions in sport: A self-regulatory perspective. In J. M. Silva, \& R. S. Weinberg (Eds.), Psychological foundations of sport (pp. 81-90). Champaign, IL: Human Kinetics.

Loyens, S. M. M., Joshua, M., \& Rikers, R. M. J. P. (2008). Self-directed learning in problem-based learning and its relationships with self-regulated learning. Educational Psychological Review, 20, 411427. doi:10.1007/s10648-008-9082-7

Marshall, H. H., \& Weinstein. R. S. (1986). Classroom context of student perceived differential teacher treatment. Journal of Educational Psychology, 78, 441-453. doi:10.1037//0022-0663.78.6.441

McAuley, E., Duncan, T., \& Tammen, V. (1989). Psychometric properties of the intrinsic motivation inventory in a competitive sport setting: A confirmatory factor analysis. Research Quarterly for Exercise and Sport, 60, 48-58.

McCarthy, P. J., Jones, M. V., \& Clark-Carter, D. (2008). Understanding enjoyment in youth sport: A developmental perspective. Psychology of Sport and Exercise, 9, 142-156. doi:10.1016/j.psychsport.2007.01.005

Morgan, K., Kingston, K., \& Sproule, J. (2005). Effects of different teaching styles on the teacher behaviours that influence motivational climate and pupils' motivation in physical education. European Physical Education Review, 11, 257-285. doi: $10.1177 / 1356336 \times 05056651$

Mosston, M. (1966). Teaching physical education. Columbus, OH: Merrill. 
Mosston, M., \& Ashworth, S. (1994). Teaching physical education. Columbus, $\mathrm{OH}$ : Charles E. Merrill.

Mosston, M., \& Ashworth, S. (1986). Teaching physical education (4 ${ }^{\text {th }}$ ed.). New York: Mcmillan.

Mosston, M., \& Ashworth, S. (2002). Teaching physical education (5th ed.). Boston: Benjamin Cummings.

Nicholls, J. G. (1984). Achievement motivation: Conceptions of ability, subjective experience, task choice, and performance. Psychological Review, 91, 328-346. doi:10.1037//0033-295X.91.3.328

Nicholls, J. G. (1989). The competitive ethos and democratic education. Cambridge, MA: Harvard University Press.

Ommundsen, Y. (2003). Implicit theories of ability and self-regulation strategies in physical education classes. Educational Psychology, 23, 141-157. doi:10.1080/01443410303224

Ommundsen, Y. (2006). Pupils' self-regulation in physical education: The role of motivational climates and differential achievement goals. European Physical Education Review, 12, 289-315. doi:10.1177/1356336X06069275

Otero, J., \& Campanario, J. (1992). The relationship between academic achievement and metacognitive comprehension monitoring ability of Spanish secondary school students. Educational and Psychological Measurement, 52, 419-430. doi:10.1177/0013164492052002017

Papaioannou, A., \& Kouli, O. (1999). The effect of task structure, perceived motivational climate and goal orientations on students' task involvement and anxiety. Journal of Applied Sport Psychology, 11, 51-71. doi:10.1080/10413209908402950

Papaioannou, A., Ampatzoglou, G., Kalogiannis, P., \& Sagovits, A. (2008). Social agents, achievement goals, satisfaction and academic achievement in youth sport. Psychology of Sport and Exercise, 9, 122-141. doi:10.1016/j.psychsport.2007.02.003

Papaioannou, A., Milosis, D., Kosmidou, E., \& Tsigilis, N. (2007). Motivational climate and achievement goals at the situational level of generality. Journal of Applied Sport Psychology, 19, 38-66. doi:10.1080/10413200601113778

Papaioannou, A., Simou, T., Kosmidou, E., Milosis, D., \& Tsigilis, N. (2009). Goal orientations at the global level of generality and in physical education: Their association with self-regulation, affect, beliefs and behaviours. Psychology of Sport and Exercise, 10, 466-480. doi:10.1016/j.psychsport.2009.01.003

Parsons, J. E., Adler, T. F., \& Kaczala, C. M. (1982). Socialization of achievement attitudes and beliefs: Parental influences. Child Development, 53, 310-321. doi:10.2307/1128973

Petlichkoff, L. M. (2003). Self-regulation skills for children and adolescents. In M. R. Weiss (Ed.), Developmental sport and exercise psychology: A lifespan perspective (pp. 269-288). Morgantown, WV: Fitness Information Technology.

Pintrich, P. R. (2000). Multiple goals, multiple pathways: The role of goal orientation in learning and achievement. Journal of Educational Psychology, 92, 544-555. doi:10.1037//0022-0663.92.3.544

Pintrich, P. R., \& De Groot, E. V. (1990). Motivational and self-regulated learning components of classroom academic performance. Journal of Educational Psychology, 82, 33-40. doi:10.1037/0022-0663.82.1.33

Pintrich, P. R., \& Garcia, T. (1991). Student goal orientation and selfregulation in the college classroom. In Advances in motivation and achievement (Vol. 7). Greenwich, CT: JAI Press.

Schraw, G., \& Dennison, R. S. (1994). Assessing metacognitive awareness. Contemporary Educational Psychology, 19, 460-475. doi:10.1006/ceps.1 994.1033

Silverman, S., \& Skonie, R. (1997). Research on teaching in physical education: An analysis of published research. Journal of Teaching in Physical Education, 16, 300-311.

Solmon, M. A., \& Boone, J. (1993). The impact of student goal orientation in physical education classes. Research Quarterly for Exercise and Sport, 64, 418-424.
Solmon, M. A., \& Lee, A. M. (1997). Development of an instrument to assess cognitive processes in physical education classes. Research Quarterly for Exercise and Sport, 68, 152-160.

Stipek, D., \& Hoffman, J. (1980). Children's achievement-related expectancies as a function of academic performance histories and sex. Journal of Educational Psychology, 72, 861-865. doi:10.1037/0022-0663.72.6.861

Theodosiou, A. (2004). Metacognitive strategies and motivation climate in physical education. Unpublished Doctoral Dissertation, Komotini: Democritus University of Thrace.

Theodosiou, A., \& Papaioannou, A. (2006). Motivational climate, achievement goals and metacognitive activity in physical education and exercise involvement in out-of-school settings. Psychology of Sport and Exercise, 7, 361-379. doi:10.1016/j.psychsport.2005.10.002

Theodosiou, A., Mantis, K., \& Papaioannou, A. (2008). Student selfreports of metacognitive activity in physical education classes. Agegroup differences and the effect of goal orientations and perceived motivational climate. Educational Research and Reviews, 3, 353-364.

Theodosiou, A., Papaioannou, A., \& Mantis, K. (2005). Factor structure and discriminant validity of the metacognitive processes in physical education questionnaire. Scientific Annuals of Psychological Society of Northern Greece, 3, 91-118.

Thill, E., \& Brunel, P. (1995). Ego involvement and task involvement: Related conceptions of ability, effort, and learning strategies among soccer players. International Journal of Sport Psychology, 26, 81-97.

Tsigilis, N., \& Theodosiou, A. (2003). Temporal stability of the intrinsic motivation inventory. Perceptual and Motor Skills, 97, 271-280. doi:102466/PMS.97.4.271-280

Veenman, M. V. J., Van Hout-Wolters, B. H. A. M., \& Afflerbach, P. (2006). Metacognition and learning: Conceptual and methodological considerations. Metacognition and Learning, 1, 3-14. doi:10.1007/s11409-006-6893-0

Viciana, J., Cervello, E. M., \& Ramirez-Lechga, J. (2007). Effect of manipulating positive and negative feedback on goal orientations, perceived motivational climate, satisfaction, task choice, perception of ability, and attitude toward physical education lessons. Perceptual and Motor Skills, 105, 67-82. doi:10.2466/PMS.105.5.67-82

Vrugt, A., \& Oort, F. J. (2008). Metacognition, achievement goals, study strategies and academic achievement: Pathways to achievement. Metacognition and Learning, 30, 123-146. doi:10.1007/s11409-008-9022-4

Weinstein, R. S., \& Middlestadt, S. E. (1979). Student perception of teacher interactions with male high and low achievers. Journal of Educational Psychology, 71, 421-431 doi: $10.1037 / 0022-0663.71 .4 .421$

Xiang, P., McBride, R., \& Bruene, A. (2003). Relations of parents' beliefs to children's motivation in an elementary physical education running program. Journal of Teaching in Physical Education, 22, 410-425.

Zimmerman, B. J. (1986). Becoming a self-regulated learner: Which are the key subprocesses? Contemporary Educational Psychology, 11, 307-313. doi:10.1016/0361-476X(86)90027-5

Zimmerman, B. J. (2000). Attaining self-regulation: A social cognitive perspective. In M. Boekaerts, P. R. Pintrich, \& M. Zeidner (Eds.), Handbook of self-regulation (pp. 13-39). New York: Academic Press. doi:10.1016/B978-012109890-2/50031-7

Zimmerman, B. J. \& Kitsantas, A. (1996). Self-regulated learning of a motoric skill: The role of goal setting and self-monitoring. Journal of Applied Sports Psychology, 8, 60-75. doi:10.1080/10413209608406308

Zimmerman, B. J., \& Kitsantas, A. (1997). Developmental phases in self-regulation: Shifting from process goals to outcome goals. Journal of Educational Psychology, 89, 29-36. doi:10.1037/0022-0663.89.1.29 